DOI: $10.35757 / R P N .2010 .18 .10$

Piotr MADAJCZYK

\title{
ECHA ROKU 1968 - WARSZAWSKIE ŚRODOWISKO HISTORYKÓW I BADANIA NAD II WOJNĄ ŚWIATOWĄ
}

Rok 1968 utrudnił politykę władz PRL wobec świata nauki. Władze te wiedziały, także na podstawie doświadczeń Marca '68, że w środowisku naukowym istnieje silna opozycja $w$ stosunku do ich polityki, a w opozycji tej są osoby o liczących się nazwiskach. W opracowaniach MSW z przełomu lat sześćdziesiątych i siedemdziesiątych przewijają się nazwiska osób, które w różny sposób łączyć można z opozycyjnym nastawieniem lub takimi działaniami: Nina Assordobraj, Bronisław Baczko, Aleksander Bardach, Zygmunt Bauman, Ludwik Bazylow, Czesław Bobrowski, Włodzimierz Brus, Janusz Groszkowski, Maria Hirszowicz, Leszek Kołakowski, Władysław Krajewski, Bogusław Leśnodorski, Stefan Morawski, Adam Schaff, Jerzy Szacki, Stanisław Turski, Stefan Żółkiewski ${ }^{1}$.

Publikowane dokumenty ukazują sytuację w Instytucie Historii PAN (IH PAN), w którym do grupy „rewizjonistycznej” zaliczano Andrzeja Ajnenkiela, Juliusza Bardacha, Wiktora Dłuskiego, Lucjana Dobroszyckiego, Bronisława Geremka, Leona Grosfelda, Tadeusza Łepkowskiego, Łukasza Hirszowicza, Jerzego Jedlickiego, Krystynę

1 Ze względu na wprowadzający charakter wstępu odsyłam jedynie do pracy J. Eislera: Marzec 1968. Geneza - przebieg - konsekwencje, Warszawa 1991 i wydawnictwa zbiorowego K. Rokicki i S. Stępień: Oblicza Marca 1968, Warszawa 2004. Część nazwisk wymienianych w publikowanych dokumentach znajdujemy we wspomnianej publikacji Rokickiego i Stępnia. 
Kersten, Jana Lewandowskiego, Walentynę Najdus, niekiedy także Janusza Żarnowskiego. Ministerstwo Spraw Wewnętrznych (MSW) podsumowywało po wydarzeniach 1968 roku swoje oceny dotyczące "grupy rewizjonistycznej”: „Grupa ta mimo zachowania istotnych wpływów - nie ma już takiego znaczenia, jakie miała w okresie wydarzeń marcowych. Spowodowane to zostało wzrostem znaczenia ludzi o właściwej postawie politycznej oraz opracowaniem konstruktywnego planu badań naukowych Instytutu Historii PAN". Zmian dokonano także w Instytucie Filozofii i Socjologii, gdzie reorganizację połączono z objęciem trzech zespołów badawczych przez prof. Jerzego J. Wiatra, doc. Włodzimierza Wesołowskiego i doc. Bogusława Gałęskiego².

Środowisko naukowe pozostawało jednak politycznie podzielone, co wobec postępującego otwarcia na kontakty międzynarodowe ( $w$ tym na Niemcy Zachodnie) komplikowało politykę władz. W opracowaniu MSW z 1970 roku stwierdzono, że strona zachodnioniemiecka gotowa jest do przejmowania całości kosztów wymiany naukowej. Zwiększała się wymiana osobowa, zapraszano polskich specjalistów, realizując w ocenie MSW - przez współpracę w dziedzinie nauk społecznych cele zachodnioniemieckiej polityki zagranicznej. W MSW określono tę politykę stypendialną jako „koncepcję dywersji ideologicznej”: indoktrynacji środowisk naukowych, budowy europejskich mostów, likwidacji różnic narodowych, zamazywania w oczach młodego polskiego pokolenia różnic ideologicznych między socjalizmem i kapitalizmem, koncentrowania się na naukach umożliwiających „lepsze zrozumienie drugiego kraju”, czyli „dywersji ideologicznej” ${ }^{3}$.

Od końca lat sześćdziesiątych następowała zmiana $\mathrm{w}$ polsko-zachodnioniemieckich kontaktach historyków, ich intensyfikowanie, a w 1970 roku ukazało się dwutomowe wydawnictwo, ukazujące całościowo problematykę okupacji niemieckiej podczas II wojny światowej: Polityka III Rzeszy w okupowanej Polsce, Czesława Madajczyka. Z punktu widzenia systemu politycznego opartego na rozbudowanej cenzurze i polityce sterowania pamięcią historyczną tworzyło

2 Por. materiały MSW z 1968 roku w IPN w Warszawie, IPN BU 0365/43, t. 2.

3 Według poufnej broszury Departamentu Szkolenia i Doskonalenia Zawodowego MSW, Problem polityki zagranicznej NRF ze szczególnym uwzględnieniem stosunków NRF-PRL, Warszawa 1973, IPN w Warszawie, IPN 0397/136. 
to problemy, o których nadmieniają publikowane dokumenty. Łączyły się one ze wzmiankowanymi już podziałami w IH PAN, ponieważ autor wspomnianego wydawnictwa pracował w IH PAN, do 1967 roku był jego wicedyrektorem, a od 1971 dyrektorem. Był także osobą zaangażowaną politycznie. Mimo członkostwa i zaangażowania w PZPR resort spraw wewnętrznych był podejrzliwy. Wyszukiwano takie sprawy, jak obejście zakazu wyjazdu do Włoch czy zbyt samodzielne działania $\mathrm{w}$ kontaktach $\mathrm{z}$ historykami zachodnioniemieckimi ${ }^{4}$. Uważnie obserwowano konflikty w środowisku naukowym związane z Marcem: „Prof. Tadeusz Daniszewski, dyrektor Zakładu Historii Partii został wezwany 19.04.1968 na zebranie partyjne. Miał wyjaśnić, czym było podyktowane jego pisemne wystąpienie do Sekretariatu KC ZPR z oskarżeniem o nacjonalizm pod adresem niektórych historyków (prof. T.[adeusza] Jędruszczaka, doc. M.[arka] Drozdowskiego). W czasie posiedzenia prof. Madajczyk wystąpił z »ostra, rzeczową i udokumentowaną« krytyką działalności ZHP i personalnie Daniszewskiego. Daniszewski przyznał się do popełnionych błędów, oraz oznajmił, że wystąpił z prośbą o zwolnienie z zajmowanej funkcji” ${ }^{5}$. Także później MSW miało wątpliwości co do politycznego zaangażowania Czesława Madajczyka, aczkolwiek oceniano go jako związanego z PZPR 6 .

4 Jak pisano, w 1967 roku był na kilkumiesięcznym stypendium w RFN i podczas pobytu zwrócił się o zgodę na wyjazd na kilka tygodni do Włoch. Sprawa skierowana została do min. Wieczorka, który zgody nie wyraził. Wtedy zwrócił się do dyrektora IH PAN, Tadeusza Manteuffla, a ten wydał zgodę na wyjazd bez konsultowania z kimkolwiek swojej decyzji. Natomiast podczas pobytu w RFN zaprosił na swoją odpowiedzialność i bez uzgodnienia z polskimi władzami siedmiu historyków z RFN na dyskusję okrąłego stołu o tematach związanych z najnowszą historią Polski. „Wobec nieformalnego załatwienia zaproszeń odmówiono na wniosek PAN wiz dla historyków niemieckich", IPN BU 001043/1282 (strony niepaginowane).

5 Notatka z 29 kwietnia 1968, ibidem.

6 W notatce tajnej, opracowanej przez L.B. z 20 stycznia 1970, ibidem, zawarto m.in. następującą charakterystykę: „Prof. Cz. Madajczyk należy do bardziej znanych i cenionych historyków średniego pokolenia. Jest specjalistą od najnowszej historii Polski, szczególnie w okresie II-giej wojny światowej. W latach 1950-1960 był dość mocno związany z środowiskiem historyków skupionych w I[nstytucie] N[auk] S[Społecznych], W[yższej] S[zkole] N[auk] S[połecznych] i Zakładzie Historii Partii, częściowo tym należy uwarunkować stosunkowo szybką karierę naukową. Od 1960 r. notuje się stopniowo wyemancypowanie Madajczyka z wspomnianego środowiska oraz usamodzielnienie naukowe. Jednak związki z tym środowiskiem nie zostały nigdy definitywnie zerwane. W czasie pełnienia funkcji z-cy dyrektora Instytutu Historii PAN starał się w spo- 
Zauważano także konflikty wokół nowego kierownictwa redakcji historycznej PWN, Edwarda Frąckiego i jego zastępcy Władysława Ważniewskiego, odpowiedzialnego za dział encyklopedyczny. Szczególnie Frącki miał być krytycznie oceniany w środowisku historyków jako nadmiernie ostrożny, zabraniający przyjmowania odważniejszych tekstów, udzielający „mentorskim tonem” rad poważnym naukowcom i zrażający ich tym do siebie (T. Jędruszczak, C. Madajczyk - uważający, że PWN inspiruje cenzurę do zastrzeżeń, Stanisław Herbst, który wycofał z PWN książkę o Powstaniu Warszawskim i przekazał do PIW). Spory powstawały też wokół pomysłu wydania „Międzynarodowego Słownika Ruchu Oporu", a IH PAN rozważał przeniesienie swoich wydawnictw do Ossolineum.

Publikowane dokumenty pokazują atmosferę końca lat sześćdziesiątych, istotne problemy ówczesnego życia politycznego i środowiska naukowego. Jednakże IH PAN ukazywany jest ze specyficznej perspektywy resortu spraw wewnętrznych. Należy je traktować z dużą ostrożnością gdyż w charakterystyczny dla MSW sposób nastawione są na wyszukiwanie podziałów i konfliktów, podczas gdy podziały polityczne nie musiały przekładać się na osobistą wrogość. Znacznie większej ostrożności i krytycyzmu wymagają oceny postaw i zachowań konkretnych osób. Atmosferę ówczesnego okresu, a nie realia, pokazuje zwłaszcza pierwszy publikowany dokument.

sób bardzo ostrożny zmienić profil osobowo-narodowościowy prac. naukowych, czynił to jednak $\mathrm{w}$ ten sposób aby nikomu się nie narazić. Nie mniej był protektorem przejścia do Instytutu Historii kilku osób z innych placówek historycznych, w tym doc. Mariana Marka Drozdowskiego, z którym pozostaje w przyjaźni.

Działalność polityczna i administracyjna oraz wystąpienia publiczne prof. Cz. Madajczyka charakteryzują się dużą ostrożnością asekuranctwem, aczkolwiek oceniany jest jako partyjny i zaangażowany naukowiec.

Jako jeden z nielicznych historyków polskich posiada dość szerokie kontakty z historykami zachodnio-niemieckimi, które nawiązał podczas kilkakrotnych pobytów w NRF. Znany jest w środowisku i swego czasu mocno komentowany fakt zaproszenia do Polski przez Madajczyka w 1967 r. podczas pobytu w NRF, siedmiu historyków zachodnioniemieckich na dyskusję dotyczącą stosunków polsko-niemieckich, bez uzgodnienia z czynnikami politycznymi (przyjazd i dyskusja nie doszły do skutku). Podczas innych pobytów za granicą nie zanotowano nielojalnej i niepartyjnej postawy Madajczyka. Wysoko oceniono jego odpowiedzialną postawę i umiejętne kierowanie delegacją historyków polskich podczas XIII Międzynarodowego Kongresu Nauk Historycznych w Moskwie w 1970 r.". 


\section{Materiały \\ 1. Źródło „Stanisław”, przyjął L.B, 22.III.1968, tajne, notatka}

(Archiwum IPN Warszawa, BU 001043/1282)

"Stanisław" scharakteryzował sytuację polityczną jaka aktualnie istnieje w Instytucie Historii PAN.

Zdaniem „Stanisława” na sytuację, która zaistniała obecnie w Instytucie Historii złożył się długoletni proces „zasilania” IH osobami narodowości żydowskiej. Głównym sprawcą tego stanu było kierownictwo Wydz. I. PAN, a personalnie - Sekretarz Wydz. I - prof. Stefan Żółkiewski. Najjaskrawszym przykładem jest narzucenie do pracy w IH dr Józefa Lewandowskiego (Lipszyca) w 1968 r., a obecnie prof. Karola Laptera, usuniętego z Partii i z pracy w WSNS za poglądy proizraelskie.

Drugim kanałem, którym „zasilano” IH wspomnianymi wyżej osobnikami była polityka stypendiów doktoranckich. Korzystano w tych przypadkach z sytuacji kiedy nieobecni byli niektórzy członkowie Kolegium kierowniczego jak - prof. Czesław Madajczyk, lub prof. Stefan Kieniewicz, pełniących funkcję wicedyrektorów IH. Prof. Tadeusz Manteuffel - dyr.[ektor] Instytutu Historii z przekonań liberał, ponadto $\mathrm{w}$ ostatnim okresie powiązany rodzinnie z środowiskiem żydowskim poprzez małżeństwo córki z dr Tomaszem Szarotą (Blüthem) - nie stanowił jakieś skutecznej tamy, nie mówiąc o prof. Leonie Grosfeldzie, który w sposób „cichy” robił wszystko, aby tego typu ludzie znaleźli się w IH.

Drugim istotnym elementem jest skład Rady Naukowej IH, również narzucony z gry, w skład której wchodzą ludzie niekompetentni i słabi naukowo, ale wywodzący się ze środowiska żydowskiego.

Jednak zdaniem „Stanisława” na Radach Naukowych, czy w kolegium kierowniczym można sobie dawać radę i przeforsować sprawy i postulaty słuszne z punktu widzenia naukowego i politycznego.

Najgorsza sytuacja zaistniała $\mathrm{w}$ organizacji partyjnej IH zmajoryzowanej przez elementy pro syjonistyczne mające głębokie związki i powiązania $z$ innymi tego typu elementami w innych placówkach naukowych przede wszystkim w Uniwersytecie Warszawskim. Sytuacja nie była jeszcze zła dopóki I Sekretarzem był doc. Marian Drozdowski, 
który mimo dużej impulsywności potrafił czasem w sposób dyktatorski narzucić swoje (zresztą słuszne) zdanie. Obecnie I Sekretarzem jest prof. Tadeusz Łepkowski, który przez dłuższy okres czasu przebywał poza krajem i nie jest zorientowany dobrze w sprawach krajowych, Wykazujący poza tym ciągoty liberalne i pewien filosemityzm, mający uzasadnienie $\mathrm{w}$ tym, że przez dłuższy okres czasu związany był naukowo z działem, kierowanym przez prof. Witolda Kulę, gdzie większość pracowników naukowych stanowią osobnicy narodowości żydowskiej. Łepkowski ponadto związany jest głęboką przyjaźnią z prof. Kulą i jego żoną - prof. Niną Assordobraj, która z kolei ma głębokie powiązania z prof. prof. Bronisławem Baczko i Leszkiem Kołakowskim oraz innymi.

Przyjacielem Łepkowskiego jest doc. Jerzy Jedlicki (brat Witolda Jedlickiego) - kreowany przez prof. Kulę na jego następcę w dziale III IH Nie bez znaczenia jest też fakt, że drugim sekretarzem jest dr. Bronisław Geremek - inteligentny i zręczny gracz, potrafiący sterować Łepkowskim w zamierzonym przez siebie kierunku.

Geremek, Jedlicki, doc. Łukasz Hirszowicz, dr Józef Lewandowski, dr Krystyna Kerstenowa, prof. Leon Grosfeld, dr Ryszarda Czepulis-Rastensis (siostra b[yłego]. lub aktualnego prac[ownika]. dep.[artamentu] kadr MSW - Barkowskiego - podkreślenie LB), dr Halina Janowska, oraz doktorant Dłuski (syn Ostapa Dłuskiego - nie będący zresztą członkiem Partii) byli tymi, którzy nadawali ton zebraniu partyjnemu i zebraniu związkowemu ZNP w IH i prześcigali się w ostrości sformułowań - mówiąc o szerzącym się w Polsce antysemityzmie, szermując hasłami braku wolności, demokracji i praworządności, w pełni solidaryzowali się z postulatami inspiratorów i prowodyrów zajść na U[niwersytecie] W[arszawskim] [UW]. Grupa ta - z uwagi na forowanie jej w wyjazdach za granicę przez kierownictwo Wydz.[iału] I PAN - mająca duże doświadczenie w ogóle a polityczne w szczególności, dysponująca poza tym lepszymi i kompetentnymi informacjami z kierowniczych kół partii, posiadająca w swoich szeregach osobników niewątpliwie inteligentnych - wykorzystała te wszystkie atuty i przez zaskoczenie narzuciła swoje postulaty.

Pocieszającym objawem - zdaniem "Stanisława" - było to, iż mimo w/wym. atutów grupy pozycyjnej znaleźli się ludzie, którzy nie inspiro- 
wani i nie będąc tak jak oni zorganizowani w sposób stanowczy sprzeciwili się poglądom i postulatom zgłaszanym przez grupę pro syjonistyczną. Należeli między innymi do nich - prof. Czesław Madajczyk, doc. Marian Drozdowski, dr Jan Borkowski, dr Eugeniusz Duraczyński. Byli oni jednak w zdecydowanej mniejszości.

"Stanisław" uważa, że zwołanie zebrania partyjnego IH już w dniu 11.III.b.r. [1968] (prawie najwcześniej spośród wszystkich placówek naukowych Wydz.[iału] I PAN) nie było dziełem przypadku. Istniała na pewno łączność pomiędzy głównymi inspiratorami z Wydz.[iału] Filozoficznego UW za pośrednictwem najprawdopodobniej dr Bronisława Geremka, doc. Jerzego Jedlickiego oraz doc. Łukasza Hirszowicza, mających silne powiązania z tym środowiskiem poprzez Małowistów (Geremek), Ninę Assordobraj (Jedlicki), Marię Bielińską-Hirszowicz (mąż Łukasz Hirszowicz). Nie wykluczone, że istnieją jeszcze inne związki o których „Stanisław” nie wie.

Charakteryzując poszczególne osoby z grupy pro syjonistycznej „Stanisław” stwierdził, że do najbardziej zaciekłych należą: doc. Jerzy Jedlicki, dr Józef Lewandowski, dr Bronisław Geremek, doc. Łukasz Hirszowicz, prof. Leon Grosfeld, dr Krystyna Kerstenowa.

Doc. Jedlicki mówił w swym wystąpieniu o coraz wzmagającej się fali antysemityzmu w nurt którego chce się skanalizować nastroje niezadowolenia społeczeństwa, o braku wolności, swobody słowa, twórczości, antyintelektualnym nastawieniu kierownictwa partii, deprecjacji nauk społecznych i t.p. Solidaryzował się z postulatami prosyjonistycznych prowodyrów wśród studentów i pracowników naukowych Wydz.[iału] Filozoficznego UW.

Inne głosy z grupy pro syjonistycznej nie odbiegały od jego, z tym, że dr Józef Lewandowski nawoływał do pójścia śladami Czechosłowacji a doc. Ł. Hirszowicz w kontekście swojego wystąpienia próbował jeszcze bronić polityki Izraela. Warto przy tym zaznaczyć, że Hirszowicz od lat w swej pracy naukowej zajmuje się nacjonalizmem arabskim i wszelkie dotychczasowe próby czynione przez prof. Madajczyka zmienienia mu tematyki zainteresowań na inny profil nie dały jak dotąd żadnych rezultatów. 
Hirszowicz nigdy nie krył się z tym, że uczuciowo związany jest z Izraelem. Dawał temu wyraz niejednokrotnie.

„Stanisław” zaznaczył, że jest bardzo ciężko, z uwagi na istniejącą sytuację w Wydz.[iale] I PAN przeprowadzić jakieś zmiany w IH. W najbliższym okresie czasu należałoby dążyć do tego, aby odsunąć od faktycznego kierowania „Kwartalnikiem Historycznym” prof. Juliusza Bardacha, gdyż podejrzewa, że jest on cenzorem artykułów dot. najnowszej historii (słusznych z punktu widzenia politycznego, których celowo nie puszcza [)]. Jest projekt stworzenia nowego pisma historycznego, poświęconego najnowszej historii, które stanowiłoby konkurencję dla redagowanego przez doc. Feliksa Tycha (zięcia J. Bermana) kwartalnika „Z Pola Walki”, który tylko jednostronnie i w „wiadomym duchu” naświetla historię ruchu robotniczego. Poprawę sytuacji politycznej w IH - „Stanisław” widzi przede wszystkim w zmianie kierownictwa Wydziału I PAN (prof. S. Żółkiewski) oraz w daniu wolnej ręki w prowadzeniu polityki kadrowej kierownictwa IH.

Mówiąc o nastrojach w środowisku historyków po ostatnich wydarzeniach na UW "Stanisław” stwierdził, że istnieją autentyczne niepokoje, czy nie pogłębi się antyintelektualny kompleks kierownictwa partii. Pogłoska o tym kompleksie od lat umiejętnie serwowana była przez środowisko żydowskie. Kilkakrotnie dała temu wyraz w swych wypowiedziach tak kompetentna osoba jak prof. Stefan Żółkiewski.

Jeśli chodzi o przemówienie tow. Gomułki, w dniu 19.III.b.r. [1968], to środowisko żydowskie IH zostało nim wyraźnie usatysfakcjonowane, że zachowuje się dotychczasowy status quo w kierownictwie partyjnym. Niektórzy ludzie, którzy oczekiwali bardziej radykalnego stanowiska są wyraźnie zwiedzeni.

\section{Dyskusje o wydaniu „Polityki III Rzeszy w okupowanej Polsce” Archiwum IPN Warszawa, BU 001043/1282.}

Józef Siemek do sekretarza KC PZPR Józefa Tejchmy, maj 1969, odpis „Przy niniejszym przesyłam odbitkę szczotkową I-go tomu publikacji Czesława Madajczyka pt ‘Okupacja Polski 1939-1945 - Polityka III Rzeszy w okupowanej Polsce' (PWN, nakład 5 tys. egz.). 
Załączam również notatkę cenzorską i opinię naczelników [Głównego Urzędu Kontroli Prasy, Publikacji i Widowisk] GUKPPiW we Wrocławiu.

Tekst, do których GUKPPiW zgłasza zastrzeżenia zaznaczono czerwonym kolorem na stronach: 29, 30, 3[?], 70, 86, 88, 91, 94, 99, 100, 146, 174, 175, 177, 186, 189, 205, 207-209, 234, 235, 250, 316, 439, 440, 477, 501.

Wydaje nam się, że najpoważniejsze obiekcje nasuwają w tym tomie trzy problemy omówione przez autora:

1/ informacja o układach niemiecko-radzieckich we wrześniu $1939 \mathrm{r}$. dotyczących Polski (s. 30, 31, 94);

2/ wzmianki o Katyniu (s. 174, 175, 177, 189);

3/ sytuacja społeczno-polityczna na terenach Białostocczyzny po wkroczeniu wojsk radzieckich (s. 207-209); zastrzeżenie nasuwa również włączenie tego opracowania do książki poświęconej okupacji niemieckiej.

Uwagi Urzędu zostały przekazane wydawnictwu, a za jego pośrednictwem - autorowi książki, który uwzględnił je tylko w niewielkim stopniu,

Załączam również komplet kolumn z poprawkami autorskimi".

„Okupacja Polski 1939-1945" - Czesław Madajczyk, wyd. PWN, [brak autora recenzji]

„Czesław Madajczyk w swoim obszernym dziele 'Okupacja Polski' w bardzo szerokim świetle przedstawił politykę III Rzeszy w okupowanej Polsce (taki jest zresztą podtytuł liczących około 1400 stron dwóch tomów edycji). Autor opierając się o liczne materiały archiwalne - krajowe i zagraniczne (m.in. National Archives w Waszyngtonie, Deutsches Zentralarchiv w Berlinie, Instytut Marksa-Engelsa-Lenina w Moskwie), bogatą literaturę i wspomnienia, omówił w sposób gruntowny zarówno agresję hitlerowska, aneksję, genezę i losy Generalnej Guberni (i innych terytorialnych jednostek administracyjnych utworzonych z podbitych ziem polskich) jak i politykę narodowościową prowadzoną przez okupanta, metody i wyniki akcji germanizacyjnej, politykę gospodarczą i jej skutki, warunki życia i pracy w okupowanym kraj[u], likwidację kultury polskiej, sytuację ludności żydowskiej, terror i ludobójstwo, Endlösung, zagładę Żydów polskich, system wychowania morderców, ukaranie zbrodniarzy wojennych i inne zagadnienia. 
Od strony edytorskiej pozycja budzi sporo zastrzeżeń. Wynikają one już to przy omawianiu przez autora stosunków Niemcy hitlerowskie - Związek Radziecki (m.in. reakcja ZSRR w czasie agresji hitlerowskiej na Polskę, zakamuflowana raczej przez Madajczyka sprawa Katynia), już to polityki narodowościowej III Rzeszy wobec Żydów i Polaków i wzajemnych stosunków obu narodów względem siebie w czasie okupacji, kiedy indziej przy powoływaniu się na źródła (H. Grynberg, Kultura paryska).

Problematyka żydowska, jakkolwiek ujęta przez Madajczyka dość wszechstronnie, w obecnej sytuacji politycznej wymaga chyba jeszcze szerszego naświetlenia. W pracy liczącej około 1400 stron przydałby się osobny rozdział traktujący o pomocy polskich organizacji podziemnych i społeczeństwa polskiego udzielanej Żydom (autor co prawda porusza te sprawy tu i ówdzie, ale czyni to przy omawianiu innych problemów, w sposób nieprzejrzysty, niezbyt wymowny). Gruntowniejszego przeanalizowania domaga się chyba również stosunek międzynarodowych organizacji żydowskich do tragicznego losu Żydów w okupowanej Polsce (autor napomyka o tym tylko).

Sygnalizuję strony:

t. I - 7, 29, 30, 31, 70, 91, 99, 100, 174, 175, 177, 189, 208, 209, 228, 234, $235,250,439-440,477,504$.

t. II - 89, 172, 216, 303, 318, 327, 330, 331, 333, 334, 336, 337".

„Okupacja Polski 1939-1945” - Cz. Madajczyk [brak autora recenzji]

Po przeczytaniu ww pozycji podzielam w znacznej mierze obawy i zastrzeżenia recenzenta.

I tak np. fragmenty zaznaczone na str. 30, 31 należałoby koniecznie stonować, ze względu na ich arbitralne i ostre sformułowania, tym bardziej, że autor nie wspomina o megalomańskim geście Becka uniemożliwiającym zawarcie porozumienia ze Związkiem Radzieckim.

Sformułowanie na s. 70 wymaga chyba uściślenia. W związku z czym proponowałbym zmianę „ziemie polskie” na - „ziemie wchodzące w skład terytorium II R.P.".

Fragment zakreślony na str. 91 należałoby przeredagować. Zestawienie Niemcy i Rosja Radziecka w tym kontekście brzmi wręcz szokująco. 
Omawiana przez autora (zakreślenia na str. 174, 175, 189) sprawa Katynia wymaga oddzielnej konsultacji, tym bardziej, iż autor unika zajęcia określonego stanowiska, co sprawia, iż z jego wywodów nie wynika, że mieliśmy do czynienia $\mathrm{z}$ hitlerowską prowokacją obliczoną na wywołanie nastrojów antyradzieckich.

Na s. 208 należałoby, moim zdaniem stonować, bądź usunąć fragmenty zawierające sugestie o prowadzonej przez władze radzieckie akcji wynarodowiania Polaków.

Przeredagowania wymaga także zakreślony na str. 209, bardzo niezręcznie sformułowany fragment na temat neutralnej postawy ludności polskiej wobec skupiania Żydów w gettach.

Na str. 234 i 235 proponuję usunąć odnośnik 4 zawierający informację o braku danych na temat ilości Polaków mieszkających w ZSRR.

Str. 477 - fragment informujący o akcjach odwetowych polskich partyzantów sformułowano bardzo niezręcznie. Należy przeredagować.

W tomie drugim omawianej pracy należy usunąć fragment zakreślony na str. 89 , tom. II".

Pismo prezesa GUKPPiW, J. Siemka, z 3.06.69 do członka BP KC PZPR i Sekretarza KC PZPR Józefa Tejchmy, odpis, DN-061-1/69

„Przy niniejszym przesyłam II tom publikacji Czesława Madajczyka pt. 'Polityka III Rzeszy w okupowanej Polsce' (PWN).

Zdaniem naszego Urzędu w II tomie należałoby dokonać pewnych skreśleń wzgl. przeredagowania tekstu na stronach: 89, 131, 133, 135/136?, 171, 170, 172, 173, 179, 214, 215, 216, 224, 263?, 267?, 270, 272, 291, 303?, 327, 331, 333/334, 337/338, 340 (tekst budzący zastrzeżenia zakreślono czerwonym kolorem).

Niezależnie od wyżej podanych zastrzeżeń, dwie sprawy zasługują - naszym zdaniem - na uwagę:

1/ Wydaje się nam, że w tej publikacji pomoc społeczeństwa polskiego Żydom (podczas okupacji) zasługuje na szersze ujęcie i wyeksponowanie: w obecnej wersji jest za mało widoczna (s. 326-339) i osłabiona rozważaniami autora na temat antysemityzmu różnych grup społeczeństwa polskiego. Jesteśmy zdania, że problemowi temu należałoby poświęcić nawet oddzielny rozdział, a jeśli to nie jest możliwe - to co najmniej odrębny podrozdział w rozdziale pt. 'Endlösung'. 
Byłoby także wskazane, aby wydawnictwo PWN przesłało rozdziały 'Endlösung' (s. 304-350) i 'Polacy w obozach koncentracyjnych' (s. 271-303) do Głównej Komisji do Badania Zbrodni Hitlerowskich w Polsce, celem merytorycznej konsultacji danych zawartych $\mathrm{w}$ ob.[ydwu] rozdziałach, odnoszących się do klasyfikacji obozów koncentracyjnych i zagłady oraz strat poniesionych przez ludność polską i żydowską.

2/ Autor publikacji 'Polityka III Rzeszy w okupowanej Polsce' relacjonuje także losy ludności polskiej, ukraińskiej i żydowskiej na terenach należących przed II wojną do Polski, przyłączonych po 17 września 1939 r. do ZSRR a w czerwcu 1941 r. okupowanych przez hitlerowską Rzeszę (np. str. 140, 192, 206, 22, 225, 377).

Z podobnym ujęciem zagadnienia Urząd miał do czynienia także $\mathrm{w}$ innych publikacjach historycznych zgłaszanych do kontroli.

Zasadniczym pytaniem narzucającym się pracownikom naszego Urzędu podczas kontroli takich publikacji jest: jak traktować tereny, które w Traktacie Ryskim w 1921 r. przypadły Polsce, we wrześniu 1939 r. zostały przyłączone do ZSRR, a w 1941 r. okupowane przez Niemcy?

W dotychczasowej praktyce cenzorskiej podejmowaliśmy zawsze decyzje jednoznaczne. Jak jednak postąpić w tej publikacji, z której pośrednio można wnioskować, iż tereny te de iure należały do państwa polskiego, jakkolwiek autor tego nigdzie expressis [w tekście: Expressie] nie stwierdza?

Uprzejmie proszę Towarzysza o opinię w tej, dla codziennej pracy Urzędu, ważnej sprawie" ${ }^{\prime 7}$.

7 Dołączano także notatki odręczne z recenzji Franciszka Ryszki i Edwarda Strzeleckiego. Według Ryszki książka jest bardzo dobra: pomnikowa, odważna, odpowiedzialna w trudnych sprawach, dobra ocena Piusa XII, relacji Polacy-Żydzi itd., należy ją skierować jak najszybciej do druku. Według Strzeleckiego nie powinno być mowy o obszarze okupacji radzieckiej, a praca wymaga generalnego przepracowania. Pospieszalski sformułował pewne uwagi krytyczne, uznając, że praca odpowiada prawdzie historycznej i nadaje się do druku.

Autor nie chciał dokonać zmian proponowanych przez GUKPPiW oraz PWN. Powoływał się na opinię Zachodu. Na konferencji w Wydziale Nauki KC PZPR pod naciskiem Andrzeja Werblana zgodził się wprowadzić zmiany. Po dostarczeniu nowej wersji stwierdzono, że było to jedynie kilka nieistotnych poprawek, notatka, płk H. Walczyński, IPN BU 001043/1282. 


\section{Notatka dyr. Departamentu III, płk. Henryka Piętka o sytuacji w ważniejszych ośrodkach naukowych w kraju, 31 stycznia 1969, tajne, s. 61-73.}

(Archiwum IPN Warszawa, IPN BU 0365/43, t. 2).

W głównych ośrodkach naukowych w kraju dominują dyskusje wokół znowelizowanej ustawy o szkołach wyższych. Większość opinii jest zgodna $\mathrm{z}$ wprowadzonymi zmianami.

Dużo miejsca $\mathrm{w}$ dyskusjach między naukowcami zajmuje sprawa przekształcenia katedr $\mathrm{w}$ instytuty naukowe. $\mathrm{W}$ uczelniach o typie technicznym i ekonomicznym sądzi się, że w wyniku tej reorganizacji nastąpi bardziej efektywne wykorzystanie zdobyczy naukowych przez gospodarkę narodową. Umożliwi ona również dokonanie niezbędnych zmian kadrowych, odsunięcie od funkcji kierowniczych i pracy dydaktycznej ludzi o postawach politycznie wrogich, Wskazuje się jednocześnie na możliwość zaostrzenia się $\mathrm{w}$ okresie przejściowym antagonizmów personalnych na tle ambicjonalnym.

Wśród pracowników naukowych w Warszawie, Łodzi, Poznaniu, przede wszystkim w placówkach o profilu humanistycznym obserwuje się zjawisko krytycznej oceny postaw i działalności ludzi znanych z wrogich wystąpień w marcu ub. r. [1968].

$\mathrm{Na}$ tle pozytywnych zmian notuje się $\mathrm{w}$ dalszym ciągu tendencje do utrzymywania przez elementy opozycyjno-rewizjonistyczne zajmowanych stanowisk i wpływów.

W Instytucie Historii PAN czołowe pozycje naukowe i polityczno-społeczne były do niedawna opanowane przez elementy rewizjonistyczne. Nosicielami tych tendencji byli: L. Grosfeld, J. Bardach, T. Łepkowski, Ł. Hirszowicz, J. Jedlicki, B. Geremek, K. Kerstenowa. Postawa polityczna tych ludzi znalazła dobitny wyraz w czasie wydarzeń marcowych, kiedy to Geremek i Kerstenowa z udziałem innych opracowali ekstremistyczną $\mathrm{w}$ treści rezolucję potępiającą decyzje i postępowanie władz partyjnych i państwowych, a popierającą $\mathrm{w}$ całej rozciągłości wystąpienia i demonstracje młodzieży oraz inspirujących ją sił. W tym okresie w pełni ujawniły się rewizjonistyczne postawy tych ludzi oraz innych jak: J. Lewandowski, W. Najdus, L. Dobroszycki, W. Dłuski. 
Najbardziej zaciekli spośród nich: Ł. Hirszowicz i J. Jedlicki zostali usunięci z partii a innych ukarano różnymi karami partyjnymi (Kerstenowa, Łepkowski, Geremek, Grosfeld). Przejęcie - w marcu - kierownictwa życiem politycznym w Instytucie przez ludzi rzeczywiście zaangażowanych spowodowało pewne przyciszenie tych elementów.

Grupa ta - mimo zachowania istotnych wpływów - nie ma już takiego znaczenia, jakie miała w okresie wydarzeń marcowych. Spowodowane to zostało wzrostem znaczenia ludzi o właściwej postawie politycznej oraz opracowaniem konstruktywnego planu badań naukowych Instytutu Historii PAN. Tym niemniej grupa rewizjonistyczna zabiega aktywnie o utrzymanie dotychczasowych pozycji w poszczególnych pracowniach. Podobne zjawisko występuje również na Wydziale Historycznym UW.

Grupa ta wszelkimi siłami stara się przede wszystkim utrzymać monopol na reprezentowanie polskiej nauki historycznej w kontaktach międzynarodowych. Np. doc. J.[erzy] Tomaszewski i dr J. Lewandowski zabiegali o utrzymanie wyłącznych kontaktów z naukowcami radzieckimi i czeskimi w czasie ich przyjazdu do Polski.

Po wkroczeniu wojsk Układu Warszawskiego do CSRS T. Łepkowski, B. Geremek, K. Kerstenowa, K.[rystyna] Zienkowska, L. Dobroszycki z Instytutu Historii PAN wystąpili z PZPR, podkreślając, że czynią to $\mathrm{w}$ celu zaprotestowania przeciwko temu faktowi.

W IH PAN oceniono wówczas, że była to demonstracja polityczna obliczona na wywołanie fermentu i dalszych tego typu posunięć. (W innych placówkach naukowych wystąpiły tylko pojedyncze przypadki demonstracyjnego oddawania legitymacji partyjnych: doc. [Andrzej?] Tramer w Inst. Fizyki PAN, dr H.[anna] Geremek, dr E.[lżbieta] Grabska-Wallis z UW, doc. Z. Kozłowski z SGPiS i adiunkt UJ E. Karnaś).

W Instytucie Historii PAN ocenia się jako kompromitację kierownictwa IH forsowanie przez dyr. prof. T. Mannteuffla (wbrew stanowisku egzekutywy POP) kandydatury doc. dr. Dawida Fajnhauza na stanowisko profesora nadzwyczajnego. W końcu listopada ub.r. [1968] D. Fajnhauz zgłosił akces na stały wyjazd do Izraela.

W wyniku poparcia kierownictwa IH dla ludzi o postawach rewizjonistycznych przyjęto ostatnio do Instytutu młodego doktora M.[arcina] 
Kulę (syna prof. W.[itolda] Kuli) powiązanego z b. członkami klubu ‘Babel'. Nie przyjęto jednocześnie (choć wyraźnie zwlekano z decyzją do czasu obrony doktoratu przez M. Kulę) dr [Romualda?] Wojny, zaangażowanego członka partii i specjalisty z najnowszej historii Polski. Przez dwa lata korzystał ze stypendium doktoranckiego w IH Aleksander Litwin, którego prace (np. 'listopad 1918 r.') i wypowiedzi dyskusyjne miały wyraźny charakter rewizjonistyczny i antyradziecki, twierdził on m.in., że leninizm w odniesieniu do spraw polskich formułował oceny błędne i nieprzyjazne. Jednocześnie odmawiano stypendiów innym doktorantom, a pracownikom zaangażowanym jak np. P. Łossowski, dr W. Balcerak, prof. T. Jędruszczak starano się wyrabiać opinie, że są nacjonalistami, antysemitami i nastawionymi antyradziecko. Próby skompromitowania tych ludzi są podejmowane przez Geremka, Jedlickiego i Hirszowicz znanych $\mathrm{z}$ demonstrowania postaw rewizjonistycznych i antyradzieckich.

W Instytucie Filozofii i Socjologii PAN, gdzie elementy rewizjonistyczno-syjonistyczne odgrywały dużą rolę, pracownicy naukowi o postawach zaangażowanych wyrobili sobie obecnie znaczną pozycję i biorą udział w podejmowaniu decyzji przez dyrekcję Instytutu. Sprzeciwiono się np. zatrudnieniu w IFiS doc. M. Hirszowicz, stwierdzając, że mogłoby to jednak nastąpić w przyszłości pod warunkiem złożenia przez nią oświadczenia ustosunkowującego się do jej rewizjonistycznej działalności oraz działalności grupy, w skład której wchodziła.

Rada Naukowa IFiS i Sekretariat Naukowy Wydziału I PAN zatwierdziły nową strukturę instytutu. W pionie socjologicznym kierownikami trzech zespołów badawczych zostali: prof. J. Wiatr, doc. W. Wesołowski i doc. B. Gałęski.

Dokonana reorganizacja Instytutu Filozofii i Socjologii PAN daje już pewne dodatnie wyniki. Przede wszystkim spowodowała rozbicie dotychczasowych grup i grupek, które zainteresowane były w takim nakierunkowaniu działalności naukowej, aby dawała ona podstawy do uzyskiwania atrakcyjnych naukowych wyjazdów zagranicznych itp. Nowa organizacja spowodowała odejście od badań typu przyczynkarskiego do badań problemowych, kompleksowych, angażujących duże zespoły pracowników naukowych, Zmiany personalne dokona- 
ne w okresie pomarcowym na szczeblu dyrektorskim przyczyniły się do przyjęcia nowych form pracy naukowej i wytwarzania się bardziej prawidłowych stosunków międzyludzkich.

Ważnym momentem z punktu widzenia zmiany profilu badawczego IFiS jest podjęcie inicjatywy Instytutu Śląskiego w kierunku nawiązania współpracy. W związku z tym rozważa się możliwość utworzenia Oddziału IFiS w Katowicach. W tym celu planuje się zorganizowanie w Katowicach wspólnej konferencji naukowej poświęconej problemom klasy robotniczej z udziałem aktywu partyjnego Katowic. Nawiązanie tej współpracy otwiera dla Instytutu nowe możliwości badawcze, szczególnie dla pionu socjologicznego.

W Instytucie Filozofii i Socjologii, w porozumieniu z redakcją 'Filozofii', przygotowuje się konferencję partyjnych filozofów, która ma być poświęcona omówieniu tradycji filozofii polskiej i problemom ideologicznym. Przy tej okazji zbadano tematykę prac naukowych z dziedziny filozofii w skali kraju.

Według katalogów rozpraw doktorskich i habilitacyjnych wydawanych przez Ministerstwo Szkolnictwa Wyższego w latach 1959-66 obroniono w kraju 122 prace filozoficzne w tym 14 prac o tematyce polskiej, co daje średnio dwie rozprawy rocznie (na wszystkie ośrodki naukowe).

Brak tematyki filozofii polskiej jest jeszcze bardziej uderzający, jeśli się przeanalizuje zestawienie artykułów drukowanych w 'Studiach Filozoficznych'. W latach 1961-66 na 161 artykułów tylko 6 było tematycznie związanych z filozofią polską. Autorami prac z filozofii polskiej byli m.in.: dr Z.[dzisław] Kuksewicz, dr J.[erzy] Szacki, H.[enryk] Hinz, M.[ieczysław] Markowski z Warszawy, dr J.[akub] Bańka z Poznania. Pozostałe dotyczyły spraw filozofii europejskiej, głównie francuskiego Renesansu, Oświecenia (Rousseau), Renesansu włoskiego, holenderskiego, hiszpańskiego.

Wobec podjęcia inicjatywy wydawania nowego pisma filozoficznego (na miejsce kwartalnika 'Studia Filozoficzne') pn. 'Filozofia' (od stycznia 1969 r.) wystąpiła ze strony pewnych osób (prof. T.[adeusz] Kotarbiński, prof. W.[ładysław] Tatarkiewicz, prof. M.[aria] Ossowska, doc. A.[ndrzej] Walicki) próba bojkotu nowej redakcji. W tej sytuacji redakcja rozesłała ankietę do wielu znanych z zaangażowanej posta- 
wy pracowników naukowych w kraju, która dała bardzo pozytywny rezultat. $\mathrm{W}$ oparciu o te wyniki redakcja planuje zmianę profilu pisma i przekształcenie go w dwumiesięcznik o szerszym zasięgu. Na postawę prof. T. Kotarbińskiego niekorzystny wpływ wywiera jego żona prof. J.[anina] Kotarbińska. W rozmowie z pracownikami naukowymi o postawie zaangażowanej i patriotycznej prof. Kotarbiński stwierdza, że nie chce stać na uboczu wydarzeń politycznych. Zaznacza przy tym, że różnice między nim a ludźmi o postawie zaangażowanej i patriotycznej nie są tak duże, jak się pozornie wydaje.

W związku z wyjazdem na roczny pobyt do Kanady prof. dr Leszka Kołakowskiego w charakterze „visiting professor" na Wydziale Filozoficznym Uniwersytetu Mc Gill w Montrealu należy przypuszczać, że dokona się pewna dezintegracja grupy rewizjonistycznej warszawskiego środowiska naukowego. Dotychczas był on osobą, wokół której $\mathrm{w}$ tej czy innej formie grupowali się naukowcy o poglądach rewizjonistycznych. Wyjazd L. Kołakowskiego spowoduje zapewne dalsze rozwarstwienie grupy rewizjonistycznej. Jeżeli chodzi o IFiS PAN to dodatkowym czynnikiem powodującym ograniczenie możliwości działania dla rewizjonistów jest fakt utworzenia dla prof. L. Kołakowskiego, prof. B. Baczki i dr H.[eleny] Eilstein osobnych stanowisk naukowych, podległych bezpośrednio dyrektorowi Instytutu.

W Instytucie Nauk Prawnych PAN możliwość przejścia do Instytutu niektórych pracowników naukowych z UW jak: M.[ieczysław] Maneli, S.[tanisław] Ehrlich i J.[uliusz] Bardach, znanych jako osoby skompromitowane politycznie, wywołała wśród pracowników INP widoczne niezadowolenie. Aktualnie M. Maneli przebywa w USA, gdzie podpisał kontrakt na wykłady na okres I roku.

W Wydziale I PAN wysuwana jest koncepcja utworzenia, na bazie Zakładu Historii Stosunków Polsko-Radzieckich i Zakładu Słowianoznawstwa, Zakładu a w perspektywie Instytutu Krajów Socjalistycznych. Jest to wynikiem postulatów wysuwanych przez wielu naukowców - członków partii mówiących o konieczności podjęcia kompleksowych badań nad funkcjonowaniem systemu socjalistycznego we wszystkich krajach naszego obozu (warunkiem uzyskania właściwych wyników badań byłyby prowadzone badania międzynarodowe). 
Podkreśla się przy tym konieczność odpowiedniego doboru kadry naukowej dla projektowanego Zakładu.

W krakowskim środowisku naukowym obserwuje się istnienie luźnych grup, które na gruncie spotkań towarzyskich usiłują lansować poglądy rewizjonistyczne. Na UJ grupa młodszych pracowników naukowych, która w marcu ub.r. [1968] solidaryzowała się z wichrzycielskimi wystąpieniami studentów obecnie w rozmowach ze studentami usiłuje propagować szkodliwe politycznie poglądy. Doc. dr Edward Łukawer ([Wyższa Szkoła Ekonomiczna] WSE) - usunięty za poglądy rewizjonistyczne - skupia wokół siebie grupę pracowników naukowych z kilku wyższych uczelni Krakowa. W prowadzonych dyskusjach reprezentują oni pogląd, że wydarzenia marcowe były 'pierwszym tzw. krótkim okresem', po którym nadejdzie okres 'drugi' - doprowadzający do głębokich niekorzystnych zmian ekonomiczno-społecznych w kraju.

Miały miejsce również fakty wykorzystania zebrań Oddziału Krakowskiego Polskiego Towarzystwa Nauk Politycznych do zakamuflowanych aluzyjnych wystąpień krytycznie oceniających aktualną sytuację polityczną w kraju i stosunki społeczno-polityczne w obozie socjalistycznym. Np. w m-cu listopadzie ub.r. w czasie odczytów na temat 'Rozwój zasady suwerenności narodu' oraz 'Marksistowska a technokratyczna wizja rozwoju państwa' wypowiedzi dyskutantów (prof. A.[?, zapewne Maria] Arctowa, prof. K.[onstanty] Grzybowski, doc. K.[azimierz] Buchała, dr M.[arek] Waldenberg, doc. M.[arek] Sokołowski) zawierały m.in. takie sformułowania: 'rzeczywistość i praktyka odbiegają daleko od głoszonych założen', 'hasło, że władza należy do narodu daje tylko tarczę dla elity rządzącej', 'prawdziwą wolę narodu można poznać tylko przez referendum' itp. Ponadto [Marek] Sobolewski sugerował konieczność dopuszczenia w Polsce do głosu wszelkich sił opozycyjnych.

Na uwagę zasługują niektóre sformułowania prof. K. Grzybowskiego, który podkreślał, m.in. 'istnienie prawa do buntu, zwłaszcza w sytuacji gdy liczne apele kierowane do władzy nie skutkują'. 
Por. Sylwester Zawadzki z Warszawy w swoim odczycie w Krakowskim Oddziale akcentował konieczność, aby o rozwoju ekonomiki kraju decydowali specjaliści-fachowcy a nie politycy. W dyskusji zabierali głos m.in. prof. W.[itold?] Zakrzewski, doc. K. Buchała, dr M. Waldenberg, dr M. Sobolewski i poparli wywody prof. Zawadzkiego. Doc. Buchała dowodził m.in. na przykładzie rad narodowych, że społeczeństwo nie ma żadnego wpływu na podstawowe i istotne decyzje tych instancji. M. Waldenberg dowodził, że w Polsce możliwa jest jedynie technokratyczna wizja rozwoju społeczeństwa realizowana przez wąską grupę specjalistów.

Niektórzy pracownicy nauki z Wrocławia nadal przejawiają szkodliwe postawy polityczne, Odsunięty od pracy dydaktycznej doc. dr Leszek Dąbrowski (inspirator ekscesów marcowych na terenie Politechniki Wrocławskiej) - występuje w swym środowisku przeciwko naukowcom realizującym linię partii na uczelni. Wokół L. Dąbrowskiego obserwuje się grupowanie różnych elementów opozycyjnych. Dr Ryszard Krasnodębski, który w okresie wypadków marcowych ogłosił demonstracyjnie głodówkę wyrażając tym solidarność z wystąpieniami studentów (zwolniony z pracy w P.Wr.) - znalazł opiekunów w osobach prof. prof. Ferencewicza, [Andrzeja] Wilkońskiego i [Władysława] Ślebodzińskiego. Na terenie Katedry Matematyki P.Wr. zorganizowano zbiórkę pieniędzy na 'pożyczkę' dla Krasnodębskiego.

Prof. dr Stanisław Hartman (inspirator rezolucji Rady Wydz. Mat.Fiz. Uniwersytetu Wrocławskiego potępiającej decyzje władz w okresie wydarzeń marcowych) usiłuje skupić wokół siebie grupę naukowców aprobujących jego negatywną postawę polityczną. Hartman lansuje pogląd, że 'socjalizm spełnił już swoją rolę i stał się martwą doktryną którą można powtarzać albo nadużywać”.

W Łodzi następuje izolacja ludzi znanych z działalności rewizjonistycznej w środowisku naukowym. W wyniku tego prof. H.[enryk] Katz, doc. I.[rena] Grajewska, dr J.[an] Kodrębski (UŁ), prof. J.[erzy] Szapiro, doc. L.[udwik Jerzy] Mazurek i prof. J.[an] Goldstein (AM) unikają szerszych kontaktów i nawiązywania dyskusji. Na osłabienie aktywności tych elementów wpłynęło usunięcie szeregu osób o poglądach rewizjonistycznych i syjonistycznych z partii i z pracy w uczelniach, jak 
również wyjazd niektórych z nich na stałe do Izraela (doc. P.[aweł] Korzec, doc. K. Błaszczyk, doc. Feniksen, prof. M. Fuchs).

Przykładem dążenia do odzyskania poprzez nich pozycji jest działalność prorektora PWSTiF doc. J.[erzego] Kotowskiego, powiązanego z J.[erzym] Toeplitzem, St.[anisławem] Wohlem i R. Wajdowiczem [Wejdowiczem] zmierzającego do wyeliminowania rektora doc. [Bolesława W.] Lewickiego z kierowania uczelnią. Kotowski nie dopuszcza przy tym do krytykowania osób usuniętych z uczelni po wydarzeniach marcowych.

W środowisku poznańskim zwraca się uwagę, że wyższe uczelnie typu technicznego i rolniczego winny pracować w zakresie badawczym dla potrzeb gospodarki z pewnym wyprzedzeniem. $W$ tej chwili nie jest to możliwe, gdyż wyposażenie techniczne wyższych uczelni jest mniej nowoczesne niż przemysłu. Zdaniem wielu naukowców poprawa na tym odcinku jest czołowym zadaniem najbliższego okresu.

Po wydarzeniach marcowych za udział w ekscesach, solidaryzowanie się z elementami wichrzycielskimi oraz działalność rewizjonistyczną zwolniono w skali kraju (z uczelni, instytutów i placówek PAN) 153 pracowników nauki. W tym okresie wnioski o wyjazd emigracyjny z Polski do Izraela złożyło 160 pracowników nauki.

Istotną z punktu widzenia wychowania młodzieży szkolnej i studenckiej jest sprawa nowych podręczników. Na niektórych kierunkach jak socjologia czy ekonomia polityczna studenci muszą się uczyć z podręczników (wobec braku w zasadzie innych) opracowanych między innymi przez Z.[ygmunta] Baumana, W.[łodzimierza] Brusa.

Wymownym przykładem jest tutaj sprawa podręcznika wychowania obywatelskiego dla szkół średnich. W roku szkolnym 1966/67 Komisja d/s Programów Nauczania i Podręczników Wychowania Obywatelskiego przy MOiSW w składzie: przewodniczący Adam Schaff, członkowie - Zygmunt Bauman, Janusz Kolczyński, Adam Kruczkowski i Marian 
Żychowski pozytywnie zaopiniowała do druku podręcznik Wychowanie obywatelskie. W sierpniu 1967 r. PZWS wydrukowały podręcznik w nakładzie 351 tys. W miesiącu maju i czerwcu ub.r. [1968] podręcznik został rozprowadzony wśród młodzieży. Bezpośrednio po ukazaniu się podręcznika miały miejsce krytyczne oceny (kadra nauczająca, przedstawiciele władz szkolnych i organizacji społeczno-politycznych) podręcznika, a głównie treści rozdziału I 'Podstawowe wiadomości o społeczeństwie i prawach jego rozwoju' w opracowaniu m. innymi Z. Baumana.

W związku z powyższym MOiSW postanowiło wycofać podręcznik z programów szkół średnich (wycofanie z programu nie świadczy o wycofaniu $z$ obiegu) i w dniu 31.VII.1968 r. przesłano $\mathrm{w}$ tej sprawie odpowiednie pisma do Kuratoriów przy WRN. Jeśli uwzględni się fakt, że jest to jedyny podręcznik z w/wym. przedmiotu, to praktycznie - mimo zalecenia MOiSW nauczanie we wszystkich typach szkół średnich realizowane jest $\mathrm{w}$ oparciu o treści zawarte $\mathrm{w}$ podręczniku wycofanym z programu.

W czasie roku szkolnego 1968/69 ukażą się materiały pomocnicze w 4-ch oddzielnych broszurach.

W lipcu ub. roku MOiSW rozwiązało Komisję d/s Programów Nauczania i Podręczników Wychowania Obywatelskiego, zwalniając równocześnie z funkcji przewodniczącego A. Schaffa, a Z. Baumana z funkcji członka Komisji.

W 1968 r. Stowarzyszenie Pax dążyło do uzyskania większych wpływów w poszczególnych środowiskach naukowych w kraju, głównie w Warszawie, Poznaniu, Łodzi, Katowicach, Toruniu. W ośrodkach tych w oparciu o tzw. Kluby „Życia i Myśli”, Pax organizował konferencje naukowe, sympozja itp. spotkania na które zapraszano wytypowanych pracowników nauki. Podkreślić należy, że w tym zakresie Pax korzystał z pomocy takich naukowców jak prof. A.[lfons] Klafkowski, prof. [Juliusz?] Nowak-Dłużewski, doc. dr [Wiktor] Kornatowski i dr J.[anusz] Justyński z Torunia.

[pominięty został wykaz kilku takich spotkań] 
W dyskusjach występowały głosy krytycznie oceniające dotychczasowy system kierowania i zarządzania gospodarką narodową. Silnie akcentowano potrzebę inspiracji światopoglądowej i rolę imperatywów moralnych w pracy nad przebudową obecnej rzeczywistości.

Ponadto Pax szeroko stosuje system różnorodnych nagród i wyróżnień, z których najbardziej znana jest przyznawana corocznie nagroda im. Wł. Pietrzaka. W 1968 roku otrzymali ją za całokształt twórczości naukowej prof. Z. Rybka i prof. B. Gałęcki".

\section{Notatka dyr. Departamentu III MSW, płk. H. Piętka o aktualnej sy- tuacji w warszawskim środowisku nauk społecznych, tajne, styczeń 1970, s. 101-107. (Archiwum IPN Warszawa, IPN BU 0365/43, t. 2)}

„Po wydarzeniach marcowych 1968 r. w warszawskim środowisku nauk społecznych (Wydział I PAN i UW) wykrystalizowała się grupa naukowców aktywnie zaangażowanych w realizację polityki partii, która stała się ważnym czynnikiem w życiu politycznym i naukowym. Natomiast czołowi przedstawicie grupy rewizjonistycznej prof. prof. Adam Schaff, Stefan Żółkiewski, Leszek Kołakowski, Włodzimierz Brus, Bronisław Baczko, Stefan Morawski, Leon Grosfeld i inni zostali poddani surowej krytyce i usunięci z zajmowanych kluczowych pozycji w kierownictwie Wydziału I PAN i UW.

Dokonane posunięcia polityczne i decyzje organizacyjne w poważnym stopniu nie tylko ograniczyły zasięg ich oddziaływania politycznego, ale stworzyły również warunki do pogłębienia się pozytywnych przemian w życiu naukowym i politycznym. W sytuacji gdy czołowi rewizjoniści zostali skompromitowani, a niektórzy wyjechali, bądź zgłosili akces na wyjazd emigracyjny do Izraela, pozostali reprezentujący postawy rewizjonistyczne postanowili przeczekać niekorzystną sytuację oraz utrzymać posiadane pozycje, rezygnując z otwartego manifestowania swych poglądów i prowadzenia jawnie wrogiej działalności politycznej (ostatnią poważniejszą demonstracją rewizjonistów ze środowiska naukowego było złożenie legitymacji partyjnych przez grupę naukowców w okresie wydarzeń sierpniowych w Czechosłowacji). 
Czynnikiem poważnie osłabiającym środowiska rewizjonistyczne był wyjazd prof. dr L. Kołakowskiego do Kanady w charakterze "visiting professor". W wyniku tego została w dużej mierze zerwana łączność pomiędzy rewizjonistami uplasowanymi w naukach społecznych i w środowisku literackim, gdyż spełniał on nie tylko rolę czołowego ideologa rewizjonizmu w Polsce, ale również był osobą łączącą działania polityczne określonych osób w obu środowiskach.

Szereg zaplanowanych zmian kadrowo-administracyjnych $\mathrm{w}$ stosunku do nosicieli tendencji rewizjonistycznych i kosmopolitycznych nie zostało zrealizowanych, $\mathrm{np}$. nie usunięto $\mathrm{z}$ kierownictwa czasopisma 'Acta Poloniae Historica' dr B. Geremka oraz K. Kerstenowej. Pozwoliło to nie tylko utrzymać w ręku grupy rewizjonistycznej niektóre kluczowe pozycje, ale spowodowało, że od jesieni 1968 r. rozpoczęły się z ich strony próby odzyskiwania utraconych stanowisk. Jedną z nich była próba opanowania Rady Zakładowej IFiS PAN, gdzie na przewodniczącego usiłowano wprowadzić doc. dr Zbigniewa Wierzbickiego, a na członków między innymi Renatę Tulli i Annę Sianko, znanych z rewizjonistycznych poglądów, bądź głębokich powiązań z nosicielami tych poglądów. Próba nie udała się dzięki zdecydowanej kontrakcji czynników politycznych.

Pozycja ludzi o poglądach rewizjonistycznych i kosmopolitycznych uplasowanych w Instytucie Filozofii i Socjologii PAN uległy poważnemu osłabieniu, ponieważ wytworzony klimat odnowy politycznej i naukowej nie sprzyjał jakimkolwiek akcjom podejmowanym przez te elementy.

Znacznie niekorzystniej przedstawiała się sytuacja $w$ innych ogniwach nauk społecznych. Na przykład dyrektor Instytutu Historii PAN prof. dr Tadeusz Manteufell przeciwdziałał inicjatywom czynników politycznych, a elementy rewizjonistyczne i kosmopolityczne znalazły $\mathrm{u}$ niego opiekę i poparcie. Tadeusz Manteufell interesował się bardzo powodami wyjazdów emigracyjnych do Izraela pracowników IH - docentów Dawida Fajnhauza, Łukasza Hirszowicza i dr Lucjana Dobroszyckiego, komentując je w aspekcie rzekomych krzywd, jakie im zostały wyrządzone.

Taktyka działania sił rewizjonistycznych i kosmopolitycznych zmierzała i nadal zmierza nie tylko do utrzymania dotychczasowego stanu 
posiadania, ale również do ponownego reaktywowania wpływu na podejmowanie ważnych decyzji natury polityczno-naukowej.

Metodą działania jest stawianie czynników partyjno-administracyjnych wobec faktów dokonanych. Przykładem może być podjęcie przez b. p.o. dyrektora Instytutu Nauk Prawnych prof. dr Mariana Rybickiego oraz prof. dr Sylwestra Zawadzkiego inicjatywy zatrudnienia w INP doc. dr Janiny Zakrzewskiej, dyscyplinarnie zwolnionej z Uniwersytetu Warszawskiego. I w tym przypadku próba wprowadzenia do składu osobowego instytutu w/wym zakończyła się niepowodzeniem, dzięki jednoznacznej postawie kierownictwa partyjnego i niektórych osób $\mathrm{z}$ dyrekcji INP.

Ułatwieniem $\mathrm{w}$ realizacji tej metody działalności jest posiadanie przez grupy rewizjonistyczne i kosmopolityczne swoich przedstawicieli bądź protektorów w radach naukowych poszczególnych instytutów Wydziału I PAN i towarzystwach naukowych krajowych i międzynarodowych (np. A. Schaff - Międzynarodowe Towarzystwo Filozoficzne, Juliusz Bardach i Aleksander Gieysztor - Międzynarodowe Stowarzyszenie Historyków, Konstanty Grzybowski i Jerzy Józef Wiatr - Międzynarodowe Towarzystwo Nauk Politycznych).

W grupach rewizjonistycznych utrwala się pogląd sformułowany m.in. przed prof. dr W. Brusa, że wydarzenia marcowe były jednym z etapów ich walki. Według ich ocen słabość „ruchu marcowego” polegała na tym, że nie zdołano szerzej wejść w środowiska młodzieżowe i zbliżyć je do środowiska robotniczego. Stąd - ich zdaniem - konieczność długofalowej, obliczonej na kilka lat pracy nad organizacyjnym i politycznym przygotowaniem młodzieży akademickiej do efektywnego działania.

Nie przeprowadzenie wszystkich planowanych posunięć organizacyjnych i personalnych w ogniwach Wydziału I PAN spowodowało podjęcie przez siły rewizjonistyczne „cichej” działalności zmierzającej do neutralizowania lub nawet częściowego eliminowania wpływu na nurt życia naukowego i politycznego naukowców zaangażowanych (zarówno partyjnych jak i bezpartyjnych) w tworzeniu i realizowaniu pozytywnego programu przemian. Głośnym echem odbiła się sprawa doc. dr Józefa Paliwody (samodzielny pracownik naukowo-badawczy 
INP PAN) przeciwko któremu spreparowano zarzut popełnienia plagiatu. Przesłanki tej akcji były o wiele szersze i należy je widzieć w kontekście ogólnie toczonej alki politycznej przez aktyw partyjny Wydziału I PAN z elementami rewizjonistycznymi. Akcja ta była jedną z prób kontrataku politycznego skierowanego przeciwko zaangażowanemu politycznie aktywowi naukowemu realizowanego przy pomocy zastraszania i prób kompromitacji. Do najbardziej czynnych w stosowaniu takich metod należy zaliczyć prof. prof. T. Manteuffla, Juliusza Bardacha, Stanisława Ehrlicha, Witolda Kulę, Sylwestra Zawadzkiego, Weronikę Gostyńska, Leona Grosfelda, Tadeusza Łepkowskiego oraz dr dr Bronisława Geremka, Krystynę Kerstenową, Andrzeja Paczkowskiego, Jana Józefa Lipskiego, Romana Zimanda i innych.

$\mathrm{W}$ naukach historycznych zasygnalizowane metody działania grupy rewizjonistycznej ujawniły się silnie w czasie przygotowań do międzynarodowych zjazdów historycznych w Moskwie i Leningradzie w 1970 r. Między innymi ze składu delegacji usiłowano wymanewrować niektórych historyków partyjnych jak np. doc. dr. hab. Andrzeja Jezierskiego. Dobór tematyki polskich wystąpień, szczególnie na Kongres moskiewski dokonany został $\mathrm{w}$ ten sposób, że nie ma tam żadnego referatu dot. najnowszej historii Polski czy węzłowych zagadnień międzynarodowych dot. Polski. Podobnego 'zabiegu' dokonano również wobec kongresowego numeru 'Acta Poloniae Historica' planując umieszczenie między innymi artykułów doc. dr Feliksa Tycha i dr. Jerzego Holzera $\mathrm{w}$ celu podniesienia ich znaczenia za granicą.

Jedną z form walki z naukowcami zaangażowanymi jest pomawianie ich o nacjonalizm i szowinizm oraz nastawienie antyradzieckie. Np. doc. W. Gostyńska czyni takie zarzuty prof. dr. T.[adeuszowi] Cieślakowi na zebraniach i konferencjach naukowych, jak również przez rozsyłanie listów do różnych instytucji. Inną formą są próby uzyskania pośredniego wpływu na oceny polityczne osób znanych z konsekwentnego realizowania programu partii, celem zahamowania i zdyskredytowania ich działalności i inicjatyw. Naukowcy o postawach rewizjonistycznych i kosmopolitycznych uplasowani w naukach społecznych nadal posiadają wszechstronne kontakty z różnymi środowiskami i instytucjami naukowymi na Zachodzie. 
Starsza generacja naukowców jak prof. prof. T. Manteufell, A. Gieysztor, W. Kula, J. Bardach posiada związki na płaszczyźnie liberalno-burżuazyjnej lub masońskiej m.in. z prof. dr. F.[ernandem] Braudelem - kierownikiem VI sekcji Sorbony i prof. dr. J.[acques'em] Le Goffem. Na innej płaszczyźnie należy widzieć kontakt dr. B. Geremka ze znanym działaczem syjonistycznym i współorganizatorem tak zwanej „nowej lewicy” we Francji - wykładowcą i dyr. administracyjnym VI sekcji Sorbony Klemensem Hellerem.

Tego rodzaju związki ulegają pogłębieniu poprzez emigrujących z Polski naukowców, którzy osiedlają się a Zachodzie, jak np. prof. dr Kazimierz Łaski - Wiedeń, doc. dr I.[gnacy] Sachs - Paryż, prof. dr K.[arol] Lapter, doc. dr Stefania Fiszman-Stanisławska i dr Józef Lewandowski - Szwecja, doc. dr Emil Adler - NRF, dr Zdzisław Kochański - Austria i inni. Utrzymują oni ścisłe kontakty korespondencyjne oraz nieoficjalne (poprzez osoby emigrujące bądź wyjeżdżające służbowo) z ludźmi o postawach rewizjonistycznych pozostałymi w Polsce.

W naukach społecznych utrzymuje się jeszcze dość silne środowisko rewizjonistyczne utrudniające realizowanie programu marksistowskiego ujęcia współczesnej problematyki badawczej. Środowiska te uciekają od współczesności do spraw i problematyki czasów historycznie odległych tak w historii jak i w filozofii.

Analiza sytuacji w zakresie filozofii i socjologii pokazała zaangażowanym pracownikom IFiS PAN, że nie wystarcza eliminować wpływy rzeczników rewizjonizmu na pracę polityczną placówek naukowych i politykę naukowa, ale przede wszystkim trzeba demaskować i obnażać rewizjonizm jako fałszywy program polityczny, który stara się występować pod szyldem prawdy naukowej. Jedną ze specyficznych cech rewizjonizmu w naukach społecznych jest jego 'systemotwórczy' charakter. Wysunąwszy jakąś tezę buduje się wokół niej całą siatkę pojęć i podporządkowuje jej wszystkie analizy i oceny. W ocenie konkretnej rzeczywistości społecznej rewizjonizm charakteryzuje się niechęcią do pogłębionych analiz empirycznych.

W oparciu o tę analizę dokonana została reorganizacja strukturalna IFiS PAN, zmiany kadrowe oraz nakreślony perspektywiczny plan badawczy w celu przekształcenia instytutu w placówkę zdolną do efek- 
tywnego i szybkiego realizowania kompleksowych badań odpowiadających aktualnym zapotrzebowaniom nauki i praktyki. Z tych względów preferowane będą prace uwzględniające rozwój teorii i metodologii marksistowskiej oraz węzłowe problemy rozwoju Polski Ludowej.

W dziale filozofii główny wysiłek nakierowany jest na zintensyfikowanie rozwoju filozofii marksistowskiej (między innymi poprzez rozbudowę Zakładu Materializmu Dialektycznego) oraz pogłębianie badań nad rozwojem filozofii polskiej i myśli społecznej, zaniedbanej w poprzednim okresie.

W dziale socjologii prace koncentrować się będą głównie nad syntetycznymi opracowaniami kilku podstawowych zagadnień jak czynniki i kierunki rozwoju społeczeństwa polskiego oraz przemiany struktury społecznej. Instytut dąży do eliminowania niedociągnięć ideologicznych i politycznych $\mathrm{w}$ zakresie filozofii i socjologii i do przekształcenia się w silny ośrodek marksistowskiej filozofii i socjologii, aktywnie uczestniczący w realizacji zadań ideologicznych wysuniętych przez partię.

Ten pozytywny program działania wymaga zasilenia niektórych zakładów, zarówno w dziale filozofii jak i socjologii, nowymi ludźmi o dużych wartościach naukowo-poznawczych prowadzących badania w oparciu o metodologię marksistowską. Instytut zamierza przyciągać takich ludzi do współpracy oraz położyć duży nacisk na studia doktoranckie, które winny stać się środkiem wychowania naukowców-marksistów. 